\title{
Характеристики судинного малюнка молочних залоз у термографічному зображенні
}

У роботі розглянуті основні термограми судинного малюнка молочних залоз та їх розподіл за чотирма типами, запропонованими різними авторами. Використання в роботі сучасного термографа з матричним фотоприймачем надало можливість отримати нові значення процентного розподілу за типами судинного малюнка. Аналіз отриманих термограм різних типів судинного малюнка молочних залоз показав доцільність введення додаткового типу судинного малюнка. Вперше отримані термографічні зображення різних типів судинного малюнка молочних залоз. Обґрунтована необхідність проведення термографічної діагностики на етапі структурного формування молочних залоз для створення базового шаблону термографічного зображення з метою своєчасного виявлення в майбутньому можливих патологічних змін.

Ключові слова: молочні залози, термографія, судинний малюнок, нормотермограми.

\section{Вступ}

Теплобачення в діагностиці захворювань молочних залоз (М3) успішно використовують у медичній практиці (Draper J.W. Boag J.W., 1971; Giraund D. et al., 1973; Вишнякова Е.Г., Ленская О.П., 1979; Девятков Н.Д., 1980; Миленко Т.А. и соавт., 1981; Соболев Н.Ф. и соавт., 1981; Госсорг Ж., 1988; Розенбах В.П., Кундыня И.А., 1994; Новак О.П та співавт., 1996; Новикова Е.Е., 1996; Фоменков А.Л., 1996; Розенфельд Л.Г., Колотилов Н.Н., 2001; Вайнер Б.Г., 2004; Думанский Ю.В. и соавт., 2005; Куклицкая А.Г., Олефир Г.И., 2005; Маркель А.Л., Вайнер Б.Г., 2005; Приходченко В.В., Приходченко О.В., 2005; Аксель Е.М., 2006; Венгер Є.Ф. та співавт., 2006; Шихман С.М. и соавт., 2007; Венгер Е.Ф. и соавт., 2012; Ковальчук И.С. и соавт., 2013; Гульчий Н.В. и соавт., 2014; Котовський В.Й., Джежеря Ю.І., 2014; Лосев А.Г. и соавт., 2015). Відомо біля 30 різноманітних захворювань МЗ, з приводу яких кожна друга жінка протягом життя звертається до лікаря (Миленко Т.А. и соавт., 1981; Соболев Н.Ф. и соавт., 1981; Розенбах В.П., Кундыня И.А., 1994; Новак О.П. та співавт., 1996; Маркель А.Л., Вайнер Б.Г., 2005; Приходченко В.В., Приходченко О.В., 2005; Ковальчук И.С. и соавт., 2013; Гульчий Н.В. и соавт., 2014). Накопичений значний обсяг наукових досліджень проявів різних форм дисгормональних дисплазій та онкологічних захворювань М3 (Draper J.W., Boag J.W., 1971; Соболев Н.Ф. и соавт., 1981; Новикова Е.Е., 1996; Фоменков А.Л., 1996; Думанский Ю.В. и соавт., 2005; Маркель А.Л., Вайнер Б.Г., 2005; Шихман С.М. и соавт., 2007).

Термографічна картина МЗ характеризується значною варіабельністю та залежить від віку, гормонального статусу жінки, васкуляризації МЗ, температури навколишнього середовища.

МЗ мають досить складну внутрішню будову, компоненти якої характеризуються складною геометрією, значною неоднорідністю фізико-хімічних характеристик та індивідуальними варіаціями. На сьогодні існує ряд моделей теплових процесів у МЗ. При розробці цих моделей (Лосев А.Г. и соавт., 2015) необхідно виходити з реалістичної геометричної структури тканин із неоднорідними характеристиками, враховуючи також нитковидні сполучні тканини, дольові структури МЗ, ореолу, сосок, вивідні протоки, жирову тканину. Зазначимо дуже важливу ділянку соска, поблизу якого містяться найменші структури, температурні дані цієї ділянки найінформативніші в діагностиці онкологічних та інших захворювань МЗ.

Виділення тепла в тканинах МЗ відбувається за рахунок процесів життєдіяльності, кровотоків, що є важливим джерелом теп- лової енергії. Окремо необхідно виділити джерела теплової енергії, які зумовлені раковими клітинами, питома щільність якої визначається інтенсивністю біохімічних процесів у тканинах при типових значеннях 4000-5000 Вт/м³. Розподіл температури в біотканині суттєво змінюється при наявності пухлин.

Моніторингом захворювань МЗ є термографічна візуалізація - динамічне спостереження протягом певного періоду часу. За результатами багаторічних досліджень встановлено, що МЗ без патологічних змін мають термографічне зображення, яке не змінюється протягом часу, так само, як відбитки пальців (Кеуserlingk J.R. et al., 2001).

Первинне термографічне дослідження МЗ на етапі завершення ї розвитку (16-18 років) дозволяє отримати базовий шаблон без патології, з яким порівнюють усі майбутні термограми. При відсутності патологічних змін кожна наступна термограма збігається з початковим дослідженням незміненої тканини МЗ - нормотермограмою. Будь-які зміни, виявлені в МЗ в наступних термографічних дослідженнях, вимагають детального та комплексного обстеження профільними фахівцями для з'ясування причин виникнення цих змін.

Нормотермограми МЗ описані J.W. Draper, J.W. Boag (1971). Автори виділяють чотири типи нормотермограм: 1-й - аваскулярний, 2-й - васкулярний, 3-й - плямистий та 4-й - сітчастий.

Вивчаючи понад 5 тис. термограм M3, D. Giraund та співавтори (1973) також розділили за характеристикою судинного малюнка на 4 типи:

- А - МЗ з однаковою температурою по всій поверхні, безсудинні або зі слабким проявом судинної мережі;

- Б - помірна двобічна васкуляризація, відносно симетрична з 2-3 судинами вузької та довгої форми й постійним світінням біля внутрішньогрудного сплетіння чи біля навколососкового кружка;

- В - двобічна васкуляризація більше ніж із трьома судинами вузької та довгої форми й нормальним або дещо збільшеним перетином судин;

- Г - сіткоподібна двобічна гіперваскуляризація, що утворює справжній повірочний патерн на поверхні МЗ.

А.Г. Куклицкая, Г.И. Олефир (2005) запропонували використовувати тест-програми на етапі отримання, обробки та інтерпретації зображення вогнища патології, що передбачається, для підвищення об'єктивності термографічного методу діагностики. Згідно з результатами їх досліджень, оцінка особливостей судин- 
ного малюнка розподілена на три теплові нормотипи: аваскулярний, плямистий або васкулярний.

При відсутності патологічних змін у МЗ градієнт температури в симетричних ділянках не перевищує $0,5^{\circ} \mathrm{C}$. Температура верхніх квадрантів M3 на 1,2 ${ }^{\circ} \mathrm{C}$ вище, ніж у нижніх. D. Giraund та співавтори (1973), В.В. Приходченко, О.В. Приходченко (2005) вважають, що норма градієнта температури становить $2{ }^{\circ} \mathrm{C}$.

У дослідженнях показано, що допустимий градієнт температури не повинен перевищувати $1,5^{\circ} \mathrm{C}$ (Новикова Е.Е., 1996; Фоменков А.Л., 1996; Маркель А.Л., Вайнер Б.Г., 2005; Аксель Е.М., 2006; Шихман С.М. и соавт., 2007; Ковальчук И.С. и соавт., 2013; Гульчий Н.В. и соавт., 2014). Ці дані в подальшому підтверджені результатами клінічних досліджень.

Абсолютна температура МЗ коливається в межах $26-36$ (Приходченко В.В., Приходченко О.В., 2005). Температурні вимірювання на поверхні МЗ значною мірою залежать від щільності та густоти кровоносних судин, температура яких завжди вища за температуру прилеглих ділянок поверхні МЗ, що впливає на результати вимірювання температури в цих ділянках. Особливого значення набуває визначення градієнта температури при значній щільності судин для встановлення наявності чи відсутності патологічних змін.

\section{Об'єкт і методи дослідження}

В сучасній медицині стрімко розвиваються інноваційні діагностичні технології. В низці робіт ґрунтовно розглянуто питання застосування тепловізорів із матричним фотоприймачем та вдосконаленим програмним забезпеченням (Draper J.W., Boag J.W., 1971; Giraund D. et al., 1973; Приходченко B.В., Приходченко O.В., 2005; Баша Н.А., Шульга Л.А., 2011; Емельянов В.А., Емельянова Н.Ю., 2013; Лосев А.Г. и соавт., 2015).

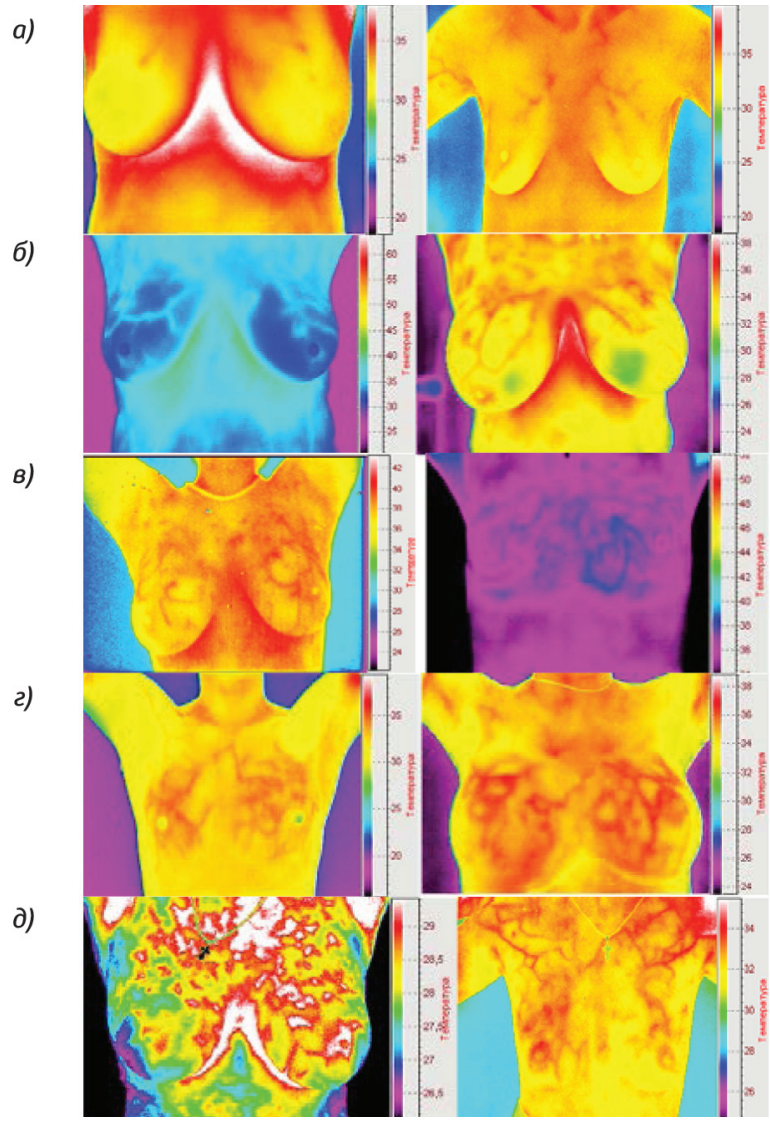

Рисунок. Розподіл термограм МЗ за типом судинного малюнка
Зросла якість отриманих термограм та підвищилось їхнє інформативне наповнення. В результаті накопиченого матеріалу з обстеження М3 розподілено термографічну візуалізацію М3 на 5 типів за характеристиками судинного малюнка з урахуванням результатів попередніх досліджень (Draper J.W., Boag J.W., 1971; Giraund D. et al., 1973; Куклицкая А.Г., Олефир Г.И., 2005; Приходченко В.В., Приходченко О.В., 2005).

В роботі використовували вітчизняний термограф з охолоджувальною фоточутливою матрицею. Методика обстеження детально викладена в роботі Є.Ф. Венгер та співавторів (2006).

\section{Результати та їх обговорення}

До 1-го типу (рисунок а) включені термограми з однаковою температурою по всій поверхні МЗ, безсудинні або зі слабким проявом судинного малюнка. Термограми МЗ з помірною двобічною васкуляризацією відносно симетричною, із 2-3 судинами вузької та довгої форми й постійним світінням біля внутрішньогрудного сплетіння або біля навколососкового кружка продемонстровані на рисунку б. Третій тип судинного малюнка МЗ (рисунок в) демонструє наявність двобічної васкуляризації з однаковим перерізом судин або збільшенням окремих судин. На рисунку г представлені термограми МЗ із сіткоподібною двобічною гіперваскуляризацією. На підставі опрацювання отриманих термограм ми визнали за доцільне введення 5-го типу характеристики судинного малюнка, для якого характерна концентрація судин різної форми та їх скупчення у верхніх квадрантах МЗ (рисунок д). Як свідчить практика, встановлення діагнозу в цьому випадку викликає певні труднощі.

Результати опрацювання розподілу термограм за типом судинного малюнка в порівнянні з даними інших дослідників представлені в таблиці.

Як вищезазначено, термографічна картина МЗ не змінюється протягом часу порівняно з термографічним зображенням, отриманим після їх фізіологічного формування (14-16 років). Це дає можливість у подальшому під час планового обстеження МЗ проводити порівняльний аналіз із попередніми термограмами. Будьяке відхилення від базової термограми МЗ повинно викликати насторогу лікаря та потребує додаткового обстеження для з'ясування причини виникнення такого відхилення.

Отриманий розподіл термографічної візуалізації за типами судинного малюнка МЗ відрізняється від попередніх даних авторів.

Під час термографічного обстеження пацієнток із 1-3-м типами судинного малюнка МЗ виявлення зон гіпо- чи гіпертермії не викликає труднощів, в той час як термографічна візуалізація патологічних змін у пацієнток з 4-м та 5-м типами судинного малюнка пов'язана з певними складнощами. Частка пацієнток із 4-м та 5-м типами судинного малюнка досить незначна - 3,73\%, але саме вони становлять групу ризику несвоєчасного виявлення онкопатології.

Як свідчать отримані результати, термографічною діагностикою з високим рівнем достовірності можуть бути охоплені 96,27\% жінок.

Наявність результатів термографічного обстеження на етапі фізіологічного формування МЗ дозволяє збільшити частку раннього скринінгу пацієнток із патологічними змінами, враховуючи незмінність судинного малюнка з віком.

\section{Висновки}

Проведений термографічний аналіз розподілу судинного малюнка МЗ порівняно з раніше описаними авторами (Draper J.W., Boag J.W., 1971; Giraund D. et al., 1973; Приходченко B.B., Приходченко О.В., 2005) нормотермограмами.

Показано, що використання сучасного термографічного обладнання дозволяє підвищити інформативність термограм для скринінгу захворювань МЗ. Запропонований новий тип характеристики судинного малюнка та нові результати процентного

Таблиця. Результати опрацювання розподілу термограм за типом судинного малюнка порівняно з даними інших дослідників

\begin{tabular}{|c|c|c|c|c|c|}
\hline \multirow{2}{*}{ Дослідження } & \multicolumn{5}{|c|}{ Типи нормотермограм } \\
\hline & 1-й & 2-й & 3-й & 4-й & 5-й \\
\hline Draper J.W., Boag J.W. (1971) & $20 \%$ & $74,4 \%$ & $5,6 \%$ & Рідко трапляється & - \\
\hline Giraund D. et al. (1973) (процентне співвідношення за типами відсутнє) & Тип A & Тип 5 & Тип B & Тип Г & - \\
\hline Куклицкая А.Г., Олефир Г.И. (2005) & Аваскулярний & Плямистий & Васкулярний & - & - \\
\hline Дані авторів роботи & $16 \%$ & $45,07 \%$ & $35,2 \%$ & $3,6 \%$ & $0,13 \%$ \\
\hline
\end{tabular}


співвідношення розподілу термографічної візуалізації за характеристиками судинного малюнка МЗ

Доцільним і необхідним є впровадження термографічної діагностики на етапі фізіологічного формування МЗ та отримання базових термограм для подальшого скринінгу пацієнток з метою своєчасного виявлення патологічних змін в МЗ.

\section{Список використаної літератури}

Аксель Е.М. (2006) Злокачественные новообразования молочной железы: состояние онкологической помощи, заболеваемость и смертность. Маммология, 1: 9-13

Баша Н.А., Шульга Л.А. (2011) Алгоритм автоматического выделения лица на термографических изображениях. Информатика и ее применение, 5(1): 73-77.

Вайнер Б.Г. (2004) Матричное тепловидение в физиологии: исследование сосудистых реакций, перспирации и терморегуляции у человека. Изд-во СО РАМН, Новосибирск, 320 с.

Венгер Е.Ф., Дунаевский В.И., Котовский В.И. и др. (2012) Современная термографическая диагностика в выявлении заболеваний биологических объектов: Зб. тез доповідей XI Міжнар. наук.-тех. конф. «Приладобудування 2012: стан і перспективи». Київ, 184 с.

Венгер Є.Ф., Дунаєвський В.І., Коллюх О.Г., Соловйов Є.О. (2006) Тепловізійна діагностика раннього виявлення захворювань людини. Электроника и связь. Биомедицинские приборы и системы. Тем. выпуск «Проблемы электроники», ч. 2. Киев, с. 79-83.

Вишнякова Е.Г., Ленская О.П. (1979) Диагностические ошибки при термографическом исследовании больных раком молочной железы и мастопатией Хирургия, 3: 107-111.

Госсорг Ж. (1988) Инфракрасная термография. Основы, техника, применение. Мир, Москва, 460 с.

Гульчий Н.В., Ковальчук И.С., Дунаевский В.И. и др. (2014) Возможности дистанционной инфракрасной термографии в диагностике заболеваний молочных желез (злокачественные изменения). Укр. мед. часопис, 3(101): 121-125.

Девятков Н.Д. (1980) Тепловидение - возможности и перспективы. Медтехника, 4: 10-12.

Думанский Ю.В., Приходченко В.В., Приходченко О.В. (2005) Организация ранней диагностики и вторичной профилактики заболеваний молочных желез в условиях общей больничной сети. Метод. рекоменд., 35 с.

Емельянов В.А., Емельянова Н.Ю. (2013) Интелектуальный метод распознавания изображений термограмм с использованием контурного анализа. Системи обробки інформації, 9(116): 22-27.

Ковальчук И.С., Дунаевский В.И., Венгер Е.Ф. и др. (2013) Возможности дистанционной инфракрасной термографии в диагностике заболеваний молочных желез (доброкачественные изменения). Укр. мед. часопис, 3(95): $165-169$

Котовський В.Й., Джежеря Ю.І. (2014) Неінвазивні технології у біомедичних дослідженнях. НТУУ «КП|», Київ, 204 с.

Куклицкая А.Г., Олефир Г.И. (2005) Повышение качества термографической диагностики в медицине. Опт. журн., 72(12): 33-36.

Лосев А.Г., Хоперсков А.В., Астахов А.С., Сулейманова Х.М. (2015) Проблемы измерения и моделирования тепловых и радиационных полей в биотканях: анализ данных микроволновой термометрии. Вест. Волгогр. гос. ун-та, 6(31): $31-71$

Маркель А.Л., Вайнер Б.Г. (2005) Инфракрасная термография в диагностике рака молочной железы (обзор иностранной литературы). Тер. арх., 10(766): 57-61.

Миленко Т.А., Миндалин С.С., Ильясов Б.Б. и др. (1981) Тепловидение в диагностике рака молочной железы. Тепловидение в медицине, ч. 2: 35

Новак О.П., Дукач В.Л., Семенюк В.О. та ін. (1996) Термографія в діагностиці захворювань грудної залози. АСТА Medica Leopoliensia, 11(2): $26-28$

Новикова E.E. (1996) Возможности термографии в диагностике заболеваний молочной железы. Автореф. ... дис. канд. мед. наук, Саратов. гос. мед. ун-т, $20 \mathrm{c}$.

Приходченко В.В., Приходченко О.В. (2005) Тепловидение в диагностике заболеваний молочных желез. Вест. неотл. восстановит. мед., 6(3): $528-531$.

Розенбах В.П., Кундыня И.А. (1994) Ранняя и дифференциальная диагностика заболевания молочной железы методом термографии. Тепловидение в медицине, 2: 30-33.

Розенфельд Л.Г., Колотилов Н.Н. (2001) Дистанционная инфракрасная термография в онкологии. Онкология, 3(2-3): 103-106.
Соболев Н.Ф., Вораско И.Х., Иванова Н.К. и др. (1981) Термографическое обследование как составная часть профилактического осмотра женщин с целью раннего выявления заболеваний молочных желез. Тепловидение в медицине, 2: 25-30.

Фоменков А.Л. (1996) Анализ морфогенеза дисплазий молочной железы. Автореф. ... дис. канд. мед. наук. Воронеж. гос. мед. акад. им. Н.Н. Бурденко, 20 с.

Шихман С.М. , Цитринбаум Б.И., Клюкин Л.М. и др. (2007) Контактная объемная термография молочных желез. Эндоскоп. хир., 6: 39-44.

Draper J.W., Boag J.W. (1971) Skin temperature distributions over veins and tumours. Phys. Med. Biol., 16(4): 645-654.

Giraund D., Altschuber C., Amalric P. (1973) Normal Mammary Thermigrama and Vascular Pafterna. Dynamic Telethermography in Clinical Oncology, p. 1-6.

Keyserlingk J.R., Ahlgren P., Yassa M., Belliveau N. (2001) Preliminary Evaluation of Digital Functional Infrared Imaging (IR) to Monitor Pre-operative Chemohormonotherapy (PCT) Induced Changes in Neo-Angiogenesis in Patients With Locally Advanced Breast Cancer (LABC) (https://onlinelibrary.wiley.com/doi/ pdf/10.1002/jso.1123).

\section{Характеристики сосудистого рисунка молочных желез в термографическом изображении}

И.С. Ковальчук, С.С. Назарчук,

В.И. Дунаевский, В.И. Котовский, С.И. Ковальчук

Резюме. В работе рассмотрены основные термограммы сосудистого рисунка молочных желез и их распределение по четырем типам, которые были предложены другими авторами. Использование в работе современного термографа с матричным фотоприемником дало возможность получить новые значения процентного распределения по типам сосудистого рисунка. Анализ полученных термограмм молочных желез показал необходимость введения дополнительного типа сосудистого рисунка. Впервые получены термографические изображения разных типов сосудистого рисунка молочных желез. Обоснована целесообразность введения термографической диагностики на этапе структурного формирования молочных желез для создания базового шаблона термографического изображения с целью своевременного выявления в будущем возможных патологических изменений.

Ключевые слова: молочные железы, термография, сосудистый рисунок, нормотермограммы.

\section{Characteristcs of the vascular pattern of mammary gland on the thermography scan}

I.S. Kovalchuk, S.S. Nasarchuk, V.I. Dunaevskiy, V.I. Kotovskiy, S.I. Kovalchuk

Summary. This work covers basic thermograms of the vascular pattern of mammary gland and their division into 4 types, which have been proposed by other authors. Using of modern thermograph with the area imager gave an opportunity to receive new value of percentage distribution in terms of vascular pattern. The analysis of the received thermograms of mammary gland revealed the necessity of addition supplementary type of vascular pattern. For the first time obtained thermographic images of different types of the vascular pattern of mammary gland. The expedience of imposition of thermographic diagnostics has been demonstrated for creation a basic pattern of thermographic image with the purpose of early recognition in future of any possible pathological changes.

Key words: mammary glands, thermography, vascular pattern, normal thermograms.

Адреса для листування:

Ковальчук Ігор Семенович

01034, Київ, вул. Рейтарська, 22

Київський міський клінічний ендокринологічний центр

E-mail: dunayevskani@ukr.net

Одержано 12.11.2018 